On the Move for Love 
PENNSYLVANIA STUDIES IN HUMAN RIGHTS

Bert B. Lockwood, Jr., Series Editor

A complete list of books in the series

is available from the publisher. 


\section{On the Move for Love}

Migrant Entertainers and the U.S. Military in South Korea

Sealing Cheng

$\overline{\text { PENN }}$

University of Pennsylvania Press

Philadelphia 
Copyright (C) 2010 University of Pennsylvania Press

All rights reserved. Except for brief quotations used for purposes of review or scholarly citation, none of this book may be reproduced in any form by any means without written permission from the publisher.

Published by

University of Pennsylvania Press

Philadelphia, Pennsylvania 19104-4112

Printed in the United States of America on acid-free paper

$\begin{array}{llllllllll}10 & 9 & 8 & 7 & 6 & 5 & 4 & 3 & 2 & 1\end{array}$

A Cataloging-in-Publication record is available from the Library of Congress ISBN 978-0-8122-4217-1 